\title{
Psychoanalytic Understanding of The Novel, 'The Tin Drum'
}

\author{
Hyeunsook Kang \\ Dr Kang's Psychiatric Clinic, Seoul, Korea
}

\section{소설 ‘양철북’의 정신분석적 이해}

\section{강 현 숙}

강신경정신과의원

The purpose of this paper is to make a psychoanalytic investigation on the novel, 'The tin drum' which was written by the Gunter Grass. For this purpose, I made a summary of the contents of the novel, and introduced Gunter Grass's autobiography which appears in his work, 'Peeling the onion.' I examined his personal history. Gunter Grass subtly expressed his unresolved oedipal conflicts in his autobiography. I have tried to analyze and interpret his novel with regard to his unresolved oedipal complex which contains and connotes multiple meanings such as patricide, love toward his mother, triangular relationships, anger, jealousy, guilt, omnipotent fantasy, masochism, regression, fixation, further development and sublimation.

Psychoanalysis 2018;29(1):1-13

KEY WORDS: Psychoanalytic understanding · The tin drum · Gunter grass · Oedipus complex.

Received: September 26, 2017 Revised: October 20, 2017 Accepted: December 26, 2017

Address for correspondence: Hyeunsook Kang, MD

Dr Kang's Psychiatric Clinic, 344 Sillim-ro, Gwanak-gu, Seoul 08754, Korea

Tel: +82-2-871-7121, Fax: +82-2-871-7122, E-mail: vhskangv@daum.net

\section{서 론}

소설 양철북의 저자인 귄터 그라스는 독일 현대문학을 대 표하는 작가이다. 1999년 스웨덴 한림원은 소설 '양철북'을 20세기의 가장 위대한 작품 중 하나라고 극찬하며, 전원 일 치로 그의 노벨문학상 수상을 결정했다. 그러나 소설 출간 후 40년이 지난 시점이어서, 그의 노벨상 수상은 뒤늦은 감 이 있었다. 그는 이미 오래전부터 세계문학 거장의 반열에 올라가 있었다. 1959년 그의 나이 32세에 양철북을 출간함 과 동시에, 그 탁월한 언어구사와 암시, 반어와 역설, 그리고 풍자가 가득한 표현으로 그의 소설은 열광적 인기를 끌었다. 하지만 다른 한편으로는 신성에 대한 모독, 그리고 외설적이 라는 이유로 격렬한 거부감을 불러일으키기도 했다(Grass 1999).

1979년에는 슐렌도르프 감독에 의해 영화화되어, 그해 칸

This is an Open Access article distributed under the terms of the Creative Commons Attribution Non-Commercial License (http://creativecommons.org/licenses/by-nc/4.0) which permits unrestricted non-commercial use, distribution, and reproduction in any medium, provided the original work is properly cited.
느영화제에서 황금종려상을 수상하였다. 워낙 유명한 소설 인 만큼 문학 비평과 연구도 많이 이루어졌다. 독문학자인 $\operatorname{Kim}(2003)$ 은 귄터 그라스의 문학과 사상에 대한 연구서인 그의 저서 '알레고리와 역사'에서 이전 연구들을 다음과 같 이 요약했다. "1963년 서독의 저명한 비평가 바겐바하는 "양 철북의 텍스트는 근본적으로 해석을 거부한다'고 결론을 내 렸다. 이 '근본적인 해석 거부'는 그 이후의 수많은 연구에도 불구하고 그다지 극복되지 않은 것 같다. 독일에서 가장 권 위있는 그라스 연구자인 폴커 노이우스마저 1976년에 “바겐 바하의 말은 그간에 있었던 수없이 많은 해석들에 의해 반 박되었다기보다는 오히려 확인되었다'고 아쉬워했다. 1992 년 앙드레 피셔의 박사학위 논문에서 이 소설의 연구 현황 에 대해 내린 결론도 희망적이지 못하기는 마찬가지다"라 고, 이 소설을 이해하고 해석하기 어렵다는 문학비평계의 혼 돈과 무기력을 토로하고 정리했다.

정신분석적 관점에서 보면 문학비평계의 혼돈과 무기력 이 놀랍다. 한 개인은 자신만의 독특한 무의식적 생을 경험 하며, 또한 동시대의 역사를 경험한다. 이 논문은 '양철북'이 귄터 그라스가 그의 시대적 상황인 나치 독일의 침략과 패 
망과 함께 겪은 개인사에 대한 자신의 심층 심리적 통찰을 담 은 자전적 소설로 볼 수 있다는 점을 탐색할 것이다. 그는 이 소설을 쓸 수밖에 없었던 심리적 동기에 대해 그의 나이 76세 에 쓴 자서전 '양파 껍질을 벗기며'에 소상히 밝혔다(Grass 2015).

그의 자서전에서 "아버지에 대한 아들의 증오, 그리스비 극의 진행과정을 이미 규정하고 있고, 프로이트와 그의 제자 들이 그토록 설득력 있는 달변을 늘어놓도록 만든 잠재의식 속의 혼란스러운 격돌은, 내가 언제나 저 멀리 있는 아득한 것을 추구하도록 만든 직접적인 원인은 아니었을지 몰라도 부가적인 동력은 되었을 것이다" (Grass 2015)라고 해결되지 않은 오이디푸스 소망과 창작심리의 연관성을 언급했으며, 그의 자서전 전반에서 자신의 해결되지 않은 오이디푸스기 소망이 자신에게 어떤 영향을 주고, 어떻게 행동하게 했는지 소상히 밝히고 있다.

일찍이 Freud(1908a)는 서로 완전히 다른 인간행위, 즉 신 경증적 증상과 농담과 유머, 실수, 꿈, 백일몽, 예술적 창작 사이의 일관된 유사성이 있다는 점을 발견했다. 신경증적 고 통과 꿈, 예술적 창작 사이에 있는 공통점은, 그들이 일상에 서 긴장을 유발하는 무의식적 요구와 화해하기 위해 투쟁한 다는 것에 있다. Freud는 작가의 예술 활동은 꿈과 같이 그 의 무의식적 소망이 의식세계에서 받아들여질 수 있도록 위 장되어 나오는 '소망 충족'으로 파악했고, 둘 다 그 구조상 이야기를 공유한다는 점에서 예술과 문학이 연관된다는 것 을 알았다.

이 논문은 우선적으로 오이디푸스기 갈등의 정신분석적 의미를 고찰할 것이며, 작가의 미해결된 오이디푸스 갈등이 그의 인생 전반에 끼친 영향을 고찰할 것이고, 그 갈등이 소 설 양철북에서 어떻게 표현되었는지 이해하기 위해 소망과 두려움, 분노와 질시, 삼각관계, 죄책감 측면에서 세밀하게 고찰할 것이다. 이 과정을 통해, 우리는 한 개인의 무의식적 갈등이 시대적 사건과 맞물릴 수밖에 없는, 우리의 운명의 일면을 목격하고 이해할 수 있게 될 것이라 생각한다. 잘 번 역된 소설 '양철북'(Grass 1999)과, 2006년에 귄터 그라스 자 신이 쓰고, 우리나라에서는 2015년 번역된 그의 자서전 '양 파 껍질을 벗기며'를 읽을 수 있어 이 작업이 용이했다.

\section{본 론}

\section{귄터 그라스의 삶}

그의 삶과 개인력의 기술은 주로 그 자신이 쓴 자서전 (Grass 2015)에 의거했다. 1927년 폴란드의 단치히 근교에서 외아들이며 장남으로 태어났다. 세 살 아래인 여동생이 있었
다. 그의 고향 단치히는 독일 접경지역으로 원래 폴란드령이 었다가 2차 세계대전이 시작되며 독일령, 독일 패망 후 다시 폴란드령이 된다. 역사의 풍파와 갈등이 있는 지역이었으며, 여러 민족이 사는 곳이었다. 소설 양철북의 무대가 되는 곳 이다. 아버지는 독일인이었고, 어머니는 카슈바이계 폴란드 인이었다. 어머니는 가톨릭 신자였다. 그의 부모는 식료품점 을 운영하던 소상인이었으며(소설 속 오스카 부모나 계모의 직업과 동일하다), 경제적으로는 어려운 편이었다. 어머니는 전쟁 때문에 세 명의 오빠가 전사하고 부모도 일찍 사별한 슬픔이 있었고, 그래서 더욱 온갖 애정을 자신의 보물인 외 아들 귄터 그라스에게 쏟아 부었다. 자신이 열네 살까지 어 머니 품을 떠나지 않고, 어머니의 응석받이로 살았다고 했으 며, 일생 동안 어머니와는 정서적으로 아주 친밀한 관계였다. 귄터 그라스가 학업에서 부진했지만, 어머니는 젊은 나이에 죽은 오빠들의 예술에 대한 사랑과 재능이 자신의 아들에게 있다고 믿었으며, 귄터 그라스는 어린 시절에 이를 삶의 이 정표로 삼았다고 했다. 전쟁의 질고를 겪었으며 귄터 그라스 가 작가로 성공하는 것을 보지 못하고, 암에 걸려 사망한다. 그의 아버지는 가족을 위해 헌신하고 부인과 금술이 좋았다. 그러나 독일이 제 1 차 세계대전에 패망한 후 등장한 나치당 에 가입했던 전형적인 독일 소시민이었다. 그는 자신의 아버 지에 대해, 생의 쾌락을 추구하고 걱정이 없으며, 쉽사리 잘 못된 유혹에 빠지고, 언제나 자제심을 얻기 위해 애썼던 남자 라고 묘사했다. 귄터 그라스가 독서에 빠져있으면 "책은 아 무리 읽어도 배가 부르지 않아”라고 소리치던 사람이었고, 아들도 식품점 주인이 되기를 원했다. 아버지와는 성장기 내 내 심각한 갈등 관계였으나, 아버지가 가족의 평화와 화합을 중시하는 분이어서 겉으로 드러나는 문제가 되지는 않았다. 그의 생전에 자신의 아들인 귄터 그라스가 작가로 대성하는 것을 봤으며, 이를 몹시 자랑스러워했다.

귄터 그라스는 중고등학교를 다니다 학업부진으로 중퇴했 다. 어머니에게 근심을 끼치고 개인적인 좌절을 겪었으나, 이 시절 처음으로 미술 등 예술적인 취향이 있음을 경험했다. 이 시기는 히틀러의 나치당이 집권당이 되며 전 세계를 상대 로 전쟁을 벌이던 격동의 시기였다. 그라스는 십대 청소년기 였던 당시에 대해 “그 시절은 흥미롭고 유혹적이었다. 총통 의 연설, 소년단원들의 북소리, 전격전, 끝없는 정복과 승리, 전투기와 유보트의 영웅과 번쩍이는 훈장, 내가 성장했던 그 곳의 여러 장소에서 전쟁이 동시에 발발했을 때 나의 어린 시절은 끝났다"고 회상했다. 1944년, 그의 나이 17세 때 나 치 친위대 신분으로, 공군 보조병, 전차병으로 참전한다. 그 러나 그가 참전했던 1944년은 이미 독일의 패색이 짙을 때 였으며, 그는 체포되어 미군의 전쟁 포로가 된다. 1945년 독 
일 패망 후 그는 1946년에 석방되어 몇 년간 석공으로 일한 다. 1949년 뒤셀도르프 예술대학에 입학했다 베를린으로 이 주하며 베를린 조형예술 대학에서 조각을 배운다. 이때 재즈 트리오를 결성해서 매주 세 차례 주점에서 연주를 하는데, 그는 주름진 양철판을 두드리는 타악기 주자였다. 석공으로 일한 경험이나 타악기 주자는 양철북의 주인공 오스카의 직 업이기도 하다. 독일의 패전 후, 미군의 포로수용소에서 석 방된 귄터 그라스는 고등학교 중퇴의 학력을 가진 초라한 패 잔병이었다. 초라한 패잔병으로, 생중계 되던 뉘른베르크 전 범재판을 보며 나치의 야만성과 잔학성을 목격하며, 자신도 나치 친위대였다는 비밀을 커다란 수치와 죄책감으로 간직한 채 “내가 왜 그랬을까? 왜?”라는 질문에 매달린다. 1954년, 부유한 중산층 출신의 무용수 안나 슈바르츠와 결혼하여 안 정을 얻으며, 파리로 이주한다. 일 년 후 서정시 대회에서 입 상을 해 시인으로 활동하며 전후 독일 문학동인인 〈47그룹〉 에 가입한다. 그가 양철북의 초고를 쓴 나이는 30세 때였다. 그는 “왜”라는 질문에 매달려, 양철북의 첫 문장을 발견한다. 양철북의 첫문장은 다음과 같다. "그래 사실이다. 나는 정신 병원에 수감된 환자다(Grass 1999)." 1958년, 만 30세에 나이 에 ‘양철북' 미완성 초고 강독으로 〈47그룹〉 문학상을 수상하 며, 이를 시작으로 왕성한 작품 활동을 하고 많은 문학상을 섭렵하며, 전후 가장 유명한 독일 작가가 된다. 1999년, 소설 양철북으로 뒤늦게 노벨 문학상을 수상할 때 그는 이미 세계 에서 가장 유명한 작가였다. 2006년, 79세에 자서전을 발간하 는데, 자신이 히틀러 무장친위대에 자원 복무했던 사실을 비 로소 털어놓으며 논쟁의 중심에 선다. 그는 그의 자서전에서 고백한다. "나는 온전히 자발적으로 히틀러 청소년단의 단 원이 되었다. 나의 아버지는 자유도시 단치히가 억압을 강요 당하지 않았던 1936년에 이미 나치에 가입했다. 나는 히틀 러 청소년 당원으로 믿음 깊은 소년 나치였고, 우리가 노래 로 찬양하던 그 모든 것이 산산조각 날 때까지 내가 추호도 의심치 않던 히틀러라는 그 이름을 믿었다. 나의 죄를 덜어 주느라 사람들이 우리를 타락시켰다, 이렇게 말할 수는 없다. 우리가 우리를, 내가 나를 타락시키도록 내버려두었던 것이 다. 나는 그때 너무 어렸었다는 말로 설명이 될까? 명백한 것은 내가 자발적으로 무기를 들고 군복무를 신청했다는 것 이다. 왜?(Grass 2015)" 자서전을 발간하기 전까지, 본인의 의 지와는 상관없이 나치 소년 단원이 된 것으로 알려져 있었고, 전후에는 유명한 작가로서, 좌파계의 반전 평화운동을 하는 양심적인 지식인의 대표주자 중 한 명이었다. 그러나 그가 사 망하기 6년 전인 2006년, 자신의 비밀을 털어 놓으며 논쟁의 중심에 서게 된다. 그의 모든 명예를 박탈하고 노벨문학상도 취소되어야 한다는 여론도 강력했었다. 2015년 4월 16일 영
향력 있으며 사랑받았던 작가로 사망한다.

\section{양철북의 간략한 줄거리와 주요 등장 인물}

양철북은 주인공이자 서술자인 30세의 오스카가 정신병원 에 살인자의 누명을 쓰고 수감되어, 과거를 회상하는 형식으 로 쓰여진다. 주인공 오스카의 출생지나 출생 시기, 나이가 저자인 귄터 그라스와 유사하기 때문에, 귄터 그라스가 경험 한 독일의 과거 역사와 그의 경험이 그대로 녹아있다. 상징 과 은유는 그의 무의식적 심층심리를 표현하는 방법이었다.

이 소설은 세 부분으로 나뉘는데, 그것은 오스카의 삶에서 의 결정적인 부분과 일치하며, 또한 작가 귄터 그라스의 삶의 연대기와도 일치한다. 제 1 부는 도망자의 이야기로 시작해 오스카의 어머니 아그네스와 오스카의 출생, 그리고 그의 어 린 시절과 함께 히틀러가 독일을 장악한 수정의 밤 사건으로 끝을 맺는다. 제 2 부는 히틀러의 독일이 폴란드를 침공하며 제 2 차 세계대전이 일어나는 장면이 얀 브론스키의 죽음과 함 께 묘사되며 시작된다. 결국 독일 패망과 함께 아버지 마체라 트는 사망하며, 애인이자 의붓어머니인 마리아와 어쩌면 아 들일지도 모르는 의붓동생 쿠르트와 단치히에서 이주한다. 제3부는 전후 시대의 생활과 오스카가 정신병원에 수감되는 무명지 사건이 나온다. 소설의 끝 부분에서 이야기를 엮어 가 는 현재 시점이 회상을 통해 순환적으로 연결된다.

\section{주요 등장 인물}

\section{오스카의 외조부, 요셉 콜야이체크}

외할아버지 요셉 콜야이스키는 폴란드를 위해 불을 지른 방화범으로, 도망자로 쫓기던 중 안나 브론스키의 네 겹 치 마 밑으로 숨어들어 아그네스를 임신시킨 후 결혼해 14년을 살았다. 도망자였던 콜야이체크는 신분 세탁을 하여 브랑카 라는 이름을 가진 선량한 남편이 되었고, 불 지르는 일에서 는 발을 씻었기 때문에 성냥갑만 보아도 몸을 떨었다.

\section{오스카의 어머니, 아그네스}

아그네스는 어린 시절부터 사촌인 얀 브론스키와 친밀하 게 지냈고, 얀이 징집될 당시에는 연인 같은 사이였다. 그러 나 아그네스는 야전병원에서 견습 간호사로 일하다가 환자 로 입원한 독일인 마체라트를 사귀게 된다. 그리고 1923년 알프레트 마체라트는 아그네스와 결혼하여 식료품점을 함 께 운영한다. 둘 사이에서 오스카가 태어난다. 그러나 결혼 후에도 얀 부론스키와 불륜 관계를 지속한다. 자신의 비극적 인 정열에 몰입하며, 전쟁이 시작되기 전에 생선중독으로 사 망한다. 
오스카

주인공인 오스카는 태어날 때부터 이미 정신 발육이 완성 되어 있었다. 그는 태어나는 순간 본 전구와 나방의 그림자 를 기억했으며, 오스카가 세 살이 되면 양철북을 사주겠다는 부부 사이의 대화를 듣는다. 세 살 생일에 찍은 사진에서 오 스카는 북을 가지고 있다. 빨간빛, 흰빛으로 구분해서 칠한 북이 배 앞에 매달려 있다. 그 무렵 오스카는 결심한다. 마체 라트가 원하는 정치가나 식료품상은 되지 않겠으며, 오히려 이 상태로 자라지 않고 머무르겠다고 결심한 것이다. 세 번째 생일 날, 마체라트가 닫는 것을 잊은, 지하실로 통하는 널빤 지 뚜껑이 열려 있는 것을 보았다. 오스카는 지하 시멘트 바 닥 위로 거꾸로 떨어진다. 그 후 다른 곳은 아무렇지 않은데 전혀 자라지 않는다. 그와 동시에 소리를 높게 유지하고 외치 면서 노래 부르는 일이 가능해졌다. 북을 빼앗기면 큰 소리를 지르고, 그러면 아무리 훌륭한 유리라도 박살이 나버렸다.

마체라트

아그네스의 남편이며 오스카의 아버지이다. 장애인인 아들 을 사랑하는 면모를 보이지만 오스카는 마체라트를 단지 호 적상의 아버지로 생각한다. 나치 독일의 패망 시 사망한다.

얀 브론스키

아그네스의 사촌이며 애인이다. 각자 결혼한 후에도 아그 네스와 밀회를 한다. 오스카는 그를 생부로 생각한다. 나치 독일의 폴란드 침공 시 사망한다.

마리아

오스카와 동갑이며, 아그네스가 죽은 후 마체라트와 결혼 하여 오스카의 새 엄마가 된다. 오스카의 첫 사랑이다.

쿠르트

오스카가 자신의 아들로 생각하는 이복동생이다.

투르친스키

어머니 아그네스가 사망 후 오스카가 처음 사귄 친구다.

클레프와 솔레, 쉬무

클레프와 솔레는 오스카와 연주하는 악단의 맴버들이며, 쉬무는 이들이 연주하던 양파주점의 주인이다.

도르테아

마리아병원의 간호사. 오스카의 짝사랑 대상이며 무명지 사건의 발단이 된다.
베브라

전선극장의 지도자이며 오스카의 스승이다. 그도 역시 난 장이다.

\section{정신분석적 이해와 고찰}

\section{오이디푸스 콤플렉스의 정신분석적 의미}

무의식과 오이디푸스 콤플렉스는 프로이트가 발견한 정신 분석의 근본적인 개념들이다. 그는 1896년 아버지가 세상을 떠난 후에 오이디푸스 콤플렉스 이론을 세우기 시작했으며, 14 년에 걸쳐 현재의 형태로 완성하였다. 그는 1897년 10월 15일에 플리쓰(William Fliess)에게 보낸 편지에서, 자신의 발견을 다음과 같이 서술했다. "나는 나 자신도 어머니를 사 랑하고 아버지를 질투한다는 것을 발견했소. 그리고 이제 이 것이 초기 아동기의 일반적인 현상이라고 생각하고 있소... 모든 사람들은 한때 신화 속의 오이디푸스가 되는 시기를 거친다고 생각하오(Freud 1966)." Freud(1900)가 '꿈의 해 석'에서 처음으로 이 이론을 발표했을 때, 그는 자기 자신과 다른 사람들의 꿈을 인용하여 모든 사람에게 있는 무의식적 소망과 오이디푸스 신화를 연결시켰다.

Auchincloss(2015)는 이 개념을 그의 책에서 잘 기술했다. 오이디푸스 콤플렉스는 아이와 부모 사이의 삼각관계 속에서 자신의 역할에 대한 아이의 사고와 감정들로 구성된다. 아이 가 3 세에서 6 세 사이에 나타난다. 여기에는 부모 중 한 명과 사랑의 결합을 하고, 이 사랑의 경쟁관계인 다른 부모를 제 거해버리고 싶은 소망이 포함된다. 아이는 자신이 사랑하는 부모의 가장 사랑하는 존재가 되기를 소망하며 경쟁상대인 부모로부터 보복당하게 될까봐 두려움을 가진다. 그러므로 이런 느낌은 사랑과 증오, 욕망과 질시, 희망과 절망, 경쟁과 두려움의 감정을 포함하는 복합 조직자(complex network) 가 된다. 이런 느낌의 조직자(network)는 우리의 생애 동안 지속되는 연판을 우리의 마음 깊은 곳에 형성하며 우리가 하 는 모든 행위에 영향을 준다. 어린 시절의 오이디푸스 콤플 렉스는 아이의 인지적 미성숙 때문에 비논리적이며 환상에 근거한 사고와 느낌을 포함할 수밖에 없다. 이는 인류에게 보편적으로 있는 것이며, 남녀노소에 상관없이 우리의 생애 동안 그 정신적인 영향은 지속된다. 오이디푸스 콤플렉스가 인류 보편적인 것(universal)이며, 우리 모두의 정신세계에 영구히 아로새겨지지만 이를 의식해서 알고 있는 사람은 거 의 없다. 이는 오이디푸스 소망이 점차 무의식화되며 억압의 기제 속으로 들어가기 때문이라고 했다. 오이디푸스 소망은 몇 가지 요소들에 의해 의식으로 끌어낼 수 있는데, 이는 자 신이 반대편 성의 부모에게 보복당할 것이라는 거세 불안이 
나 사랑을 잃을 것이라는 두려움과 죄책감에서 오는 두려움 들이다. 이 죄책감과 두려움은 아이가 자려며 점점 더 중요 해진다. 억압의 과정을 거치며 오이디푸스 콤플렉스는 점차 무의식적 소망과 무의식적 두려움이 된다. 그리고 이것이 후 에 새로운 정신구조를 만드는데, Freud는 이를 초자아라 했 다. 즉 이는 오이디푸스 갈망에 대한 부모로부터의 금기를 아이가 내면화(internalize)하며 형성한다고 했다. 이제 새로 형성된 초자아 또는 양심에 의해 아이는 죄책감을 느낀다. 마지막으로 오이디푸스 콤플렉스는 자신이 애착하는 대상에 대한 소망을 계속 추구하는 대신 그의 부모를 복사해서 형성 하는 동일시(identification)를 하게 하며, 이것이 자아상(self image)의 형성에 중요하다.

\section{귄터 그리스 자신의 해결되지 않은 오이디푸스기 갈등}

귄터 그라스의 자서전에 기록된 자신의 아버지에 대한 회 고는 다음과 같다.

"나의 성장기에서 제발 사라져 줬으면 했던 사람, 내가 단 칸방의 협소함과 네 가구의 셋집이 공동으로 사용하는 화장 실의 협소함에 대한 모든 죄를 돌렸던 사람, 히틀러 청소년 단의 단도로 찔러 죽이고 싶었고, 거듭해서 머릿속에서 찔러 죽였던 사람(Grass 2015)."

이와는 대조적인 어머니에 대한 회고다.

“어릴 적 콤플렉스로부터 벗어나지 못했던 이 응석받이에 게 열네 살이 될 때까지도 당신의 품을 내 주었던 어머니, 카 드놀이를 즐기고, 열 손가락을 전부 써서 방울져 떨어지는 듯 한 피아노곡을 느리게 연주하고, 나를 위해 계란 노른자에다 설탕을 넣어 휘저어 주던 어머니, 농담과 장난을 즐기고 웃 곤 하던 어머니, 일요일에 태어난 당신의 아이를 맹목적으로 믿어 주었던 어머니, 당신의 아들에게 모든 것을 베풀었으며 아들로부터 얻은 것은 적었던 어머니, 내 기쁨의 계곡이자 고통의 골짜기였던 어머니(Grass 2015)."

이 짧은 문장들에서 그의 해결되지 않았던 오이디푸스 소 망을 알 수 있다. 사춘기에 그의 무의식적이고 위험한 소망 은 고조된다.

"단칸방의 좁은 집. 나는 긴 소파가 있는 거실에서 잠을 잤 다. 그 긴 소파는 부모님의 결혼 생활의 증인이었다. 나는 나 지막하게 작아지기는 했지만 어린 시절부터 들어서 익숙했 고, 머릿속으로 기괴한 의식이라고 여겼던 것을 들었거나 들 었다고 생각한다. 시작을 알리는 속삭임, 삐꺽거리는 침대, 신음 소리, 탄식 소리, 어둠 속에서 벌어져 더욱 인상적인 성 교 특유의 그 모든 소음. 어둠 속에 누워 있는 내 눈 앞에는 성교의 모든 유희 양식이 너무도 선명하게 어른거렸다. 끝까 지 상영되는 영화에서 언제나 희생을 치르는 것은 어머니였
다. 나는 아버지와 싸우려고 시도했다. 하지만 가족의 평화 를 중시하는 아버지는 금방 누그러졌고, 아버지에게는 언제 나 화합이 중요했다. 나는 그를 도깨비로 만들려고 열심히 반죽했지만 아버지는 순순히 증오의 대상이 되어 주지 않았 다(Grass 2015)." Freud(1908b)는 아이의 많은 백일몽들이 부모의 성생활과 연관되어 있다고 했다. 그는 그것을 원초경 (primal scene)이라 했다. 원초경(primal scene)은 그것이 사 실이든 상상이든, 누구에게나 있는 보편적인 시나리오라 했 다. 그리고 아이는 부모의 침실에서 일어나는 일을 뭔가 난 폭한 행위로 연상하는 일이 흔하다고 했다. 귄터 그라스는 자신의 원초경(primal scene)을 그의 자서전에서 생생하게 기술한 것이다.

사춘기에는 잠재되어 있던 성적 관심과 성 충동이 증가하 기 때문에 오이디푸스 콤플렉스가 다시 출현한다. 그러나 이 번에는 어릴 때의 경우와 다르다. 이제는 육체적으로 성장했 고, 사정도 가능하기 때문에 근친상간의 위험이 더욱 심각하 게 느껴진다. 이성의 부모와의 갈등이 심해지는 시기이다. 위험이 크기 때문에 해결에 대한 요구도 더욱 강력하다(Lee 2006). 17세 소년이었던, 귄터 그라스의 고조되는 갈등과 고 통의 해결책은 다음과 같았다.

"나는 도주로를 탐색했다. 모든 길이 한 방향으로 달렸다. 여기서 벗어나기만 하면 돼. 전선으로. 많은 전선들 중 하나 로 가능하면 빨리 달아나자. 그리고 그 시절은 흥미롭고 유 혹적이었다. 총통의 연설, 소년단원들의 북소리, 전격전, 끝 없는 정복과 승리, 전투기와 유보트의 영웅과 번쩍이는 훈 장, 내가 성장했던 그곳의 여러 장소에서 전쟁이 동시에 발 발했을 때 나의 어린 시절은 끝났다(Grass 2015)." 이 시기는 1944년으로 제 2 차 세계대전의 말기이며, 나치 독일이 자국 민의 전능감(omnipotent wish)과 공격성(aggression)을 고 취시키던 시기였다. 귄터 그라스와 같은 무의식적 갈등을 가 진 경우는, 자신의 절망감 때문에 더욱 그 시대가 자극적이 었으리라 생각한다. 그래서 그는 전쟁이 종말을 향해 가던 때, 자신의 오이디푸스 갈등을 피하기 위한 도주로로써 전쟁 터로 향하는 길을 택해 지원 입대하게 된다.

\section{양철북을 쓴 동기가 된 무의식적 소망 충족}

독일의 패전 후, 미군의 포로수용소에서 석방된 20대의 귄 터 그라스는 고등학교 중퇴의 학력을 가진 초라한 패잔병이 었다. 그러나 가장 큰 고통은 그의 마음속에 있는 비밀스런 수치심과 죄책감이었다. 귄터 그라스는 초라한 패잔병으로, 생중계되던 뉘른베르크 전범재판을 보며, 나치의 야만성과 잔학성을 목격한다. 자신도 나치 친위대원이었으며, 자원 입 대자였다는 비밀을 수치와 죄책감으로 간직한 채 “왜”라는 
질문에 수년간 매달려, 마침내 30세에 양철북의 첫 문장을 쓴다. 사실 그 당시의 귄터 그라스 자신이 마음의 감옥에 수 감된 환자였다고 말할 수도 있다. 귄터 그라스는 그를 추악한 전범이 되게 했던, 17 세에 고조됐던 심리적 갈등, 즉 자신을 전쟁터로 도망치게 했으며 전범이 되게 만든, 미해결된 자신 의 오이디푸스기 갈등 속으로 곧장 뛰어든다. 양철북이 해결 되지 않은 오이디푸스기 갈등을 다룬 심리소설이라는 것은 누구에게나 명백하다. 양철북 줄거리의 근간을 이루는 해결 되지 않은 오이디푸스기 갈등이, 귄터 그라스에게는 “왜”라 는 질문, 즉 나치 전범이라는 비밀스럽고도 뿌리 깊게 평생 그를 따라다닌 수치심과 죄책감에 대한 무의식적인 답인 동 시에, 그의 무의식과 환상이 만든 해결책이었으며, 그리고 귄터 그라스 자신의 “왜”라는 절박한 질문에 대해, 자기 이 해를 달성했을 것이라는 측면에서, 그의 소설 양철북은 그의 소망 충족의 한 축을 담당했다고 본다. 그의 인생사에서 가 장 중요한 요인으로 추정하는 오이디푸스 콤플렉스는 '양철 북'이란 소설 안에서 어떻게 구현되고 해결되었는지 알아보 도록 하겠다.

\section{소설 양철북 속의 오이디푸스기 갈등}

귄터 그라스는, 과거는 나를 불러들였고 소설 속 인물들은 자기들의 주관을 가지고 움직였다고 했다. 소설 속의 인물들 은 그의 무의식 속에 살아 있던, 자기 자신과 대상들이 투사 된 인물들이다. 과거를 따라 잡기 위해 평소에는 쓰지 않는 단어들을 사용했다고 했다(Grass 2015). “왜?”라고 묻는 것은 놓치지 않고, 끝까지 가보기 위해 그는 묻혀 있던 모든 것을 추적한다. 주인공인 오스카 마체라트의 회상으로 그의 방대한 소설은 시작된다. 필요한 본문은, 작가의 필체의 묘미와 유 머를 살리고 싶어 가능하면 원문에서 발췌하려고 노력했다.

\section{소설 '양철북' 속의 도망자의 의미}

귄터 그라스는 그의 과거로 도망치기(regression 하기) 위 해 소설의 제일 첫 장면에 도망자를 등장시킨다. 1899년 10 월의 보슬비 내리는 석양 무렵 너른 지평선만 펼쳐지는 감 자밭에, 멀리 보이는 굴뚝과 전신주 사이에서 어른거리던 도 망자가 안나 브론스키의 치마 밑으로 숨어들며 긴 이야기의 시작을 알린다. 그는 오스카의 외조부이며 방화범인 콜라야 체크이며, 너른 들판에서 숨을 곳이라곤 거기밖에 없었던 것 이다. 긴 소설이 끝나갈 때, 양파주점에서 양철북 주자로 일 하던 28살의 오스카가 비틀라르에게 무명지를 건네주며 자 신을 살인범으로 고발하도록 시키고 한 말도 도주였다. "그 래 도주다. 나는 비틀라르의 고발의 가치를 높이기 위해 도주 했다. 유일하게 전망 있는 도주의 목적지는 할머니 안나의 네
벌 치마 쪽이다(Grass 1999)." 나는 소설 속의 오스카가 한 이 말은 사실은 28살의 귄터 그라스가 자신에게 한 말이라 고 생각한다. 28살의 귄터 그라스가 주점에서 양철로 된 드 럼을 두드리며, 소설의 첫 장면으로 도망자와 안나의 네 겹 치마를 구상했으리라 생각한다. Freud는 원초적 억압과 더 불어 고착(fixation)이 일어나며, 심리적으로 어려운 시기에 는 그 고착됐던 지점으로 퇴행하는 반복강박을 설명한 바 있 다(Freud 1963a). 즉 현실 속의 28세의 그라스는 자신이 고 착(fixation)된 지점으로 퇴행(regression)하기 위해 3세의 오 스카를 탄생시킬 도망자인 외조부를 소설에 제일 처음에 등 장시켰다고 생각한다. 오스카가 병원에 수감된 지 2년 후에 진범이 잡히며 무죄로 석방될 때 소설 속 오스카의 나이는 30세였으며, 귄터 그라스가 창작을 통해 부분적인 자기 이해 를 달성하며, 양철북의 초고를 〈47그룹〉에서 발표할 당시 작가의 나이도 30 세였다.

\section{아버지 살해}

'요리로 밖에는 자신의 감정을 표현하지 못하는 독일인'인 마체라트를 아버지(실제 자신의 아버지에 대한 묘사와 동일 하다.)로, '비극적인 정열에 몰입하며 아름다운 생선 중독자' 로 죽는 아그네스를 엄마로 주인공인 오스카가 태어난다. 세 살부터 남자아이가 겪을 무의식적 갈등이 전쟁 상황과 맞물 려 현실의 사건으로 소설의 면면에 묘사된다. 어린아이인 오 스카에 의해 자행되는 두 아버지의 살해의 이야기가 가장 뚜렷하다 할 수 있다.

자신이 생부라 생각하는 얀 브론스키는 2차 세계대전의 발발과 함께 독일인에게 죽는다. 그 경위는 다음과 같이 묘 사된다. "어머니인 아그네스가 죽은 후, 마체라트는 오로지 나치당의 업무 외에는 생각하지 않았으며, 유태인이었던 마 르쿠스의 장난감 가게도 없어졌다. 양철북을 고쳐줄 사람이 필요했던 오스카는 얀에게 같이 근무하는 폴란드 우체국 관 리인 코비엘라를 찾아가자고 부탁한다. 얀이 부탁을 들어줘 서, 같이 가게 되는데 그날 오스카는 얀과 함께 폴란드 우체 국 2층 우편물 보관실에서 제2차 세계대전을 맞게 된다. 30 명의 폴란드 우체국 직원은 독일군에 대항하여 우체국을 사 수한다. 폴란드 우체국이 포위되고 폭격을 맞고, 양철북을 고쳐준 코비엘라는 부상을 당한 상황이었다. 지하 우편물 창 고에서 오스카와 코비엘라, 얀은 계속 카드놀이를 한다. 말 하자면 그들은 게임을 함으로써 신경을 쓰도록 해 코비엘라 가 죽는 것을 금했던 것이다. 그러나 결국 코비엘라는 사망 하고 얀은 그를 깨우기 위해 노력한다. 오스카는 "내버려두 세요. 아빠 죽었어요”라고 나지막하게 말한다. 오스카에게 그날 처음 아빠라고 불리운 얀은 수위의 시체를 떼어놓고는, 
넘쳐 나올 듯이 푸른 눈으로 오스카를 바라보고는, 아니야, 아니야 하며 울며 오스카를 쓰다듬었다. 폴란드 우체국 전투 에서 체포된 얀을 포함한 30명의 폴란드인은 독일군에 의해 사살된다(Grass 1999)." 오스카가 죽인 것은 아니지만 그를 죽음의 장소로 이끈 것은, 폴란드 우체국 관리인에게 양철북 을 고치러 가자고 한 오스카였다.

호적상의 아버지라고 믿는 마체라트에 대한 살해는 더욱 노골적이다. 소설 속의 아버지인 마체라트는, 오스카에게 좋 은 아버지로 묘사된다(실제 귄터 그라스의 아버지와 유사하 다). 나치당 당원이었던 마체라트는 독일의 패망과 함께 연 합군으로 들이닥친 러시아군인들에게 죽는다. 다음은 그가 죽는 장면을 묘사한 소설의 원문이다. "러시아 군대가 가까 이 왔을 때, 오스카의 가족과 이웃은 지하실로 도피했다. 어 린아이처럼 겁을 먹은 마체라트는 지하실 한가운데 서서, 처 음으로 히틀러의 최후 승리에 대한 의혹을 표명한다. 그는 나치당의 배지를 윗저고리의 깃에서 떼어 냈지만, 그것을 어 디에 감추어야 할지 몰랐다. 그는 배지를 콘크리트 바닥에 내던지며 그것을 짓밟았다. 쿠르트가 그 배지를 향해 달려들 었으나 오스카가 그것을 먼저 집어 계속 손 안에 넣고 있었 다. 러시아 군인들이 들이닥쳤을 때 오스카는 그 배지를 자 신의 옆에 서있는 마체라트에게 손에 쥔 채 내밀었다. 마체 라트는 손을 뻗쳤고, 오스카는 배지를 놓았다. 놀란 마체라 트는 그 배지로부터 벗어나려고 했으나 자신의 목구멍 이외 에는 숨길 장소를 발견하지 못하고 말았다. 날카로운 핀이 달 린 이 처치 곤란한 배지가 그의 목구멍을 막고 말았다(Grass 1999)." 오스카의 추정상의 아버지인 마체라트는 그렇게 죽 는다.

어머니에 대한 사랑의 욕구 실현

이야기나 공상 속에서도 친어머니와의 근친상간은 아버 지 살해보다 횔씬 접근키 어려운 금기인가 보다. 그는 사랑 의 대상으로, 마리아라는 오스카 나이 또래의, 그러나 어머 니를 연상시키는 계모를 등장시킨다. "죽은 투르친스키의 막내 동생 마리아는 홀아비가 된 마체라트의 살림과 가게 일을 도와주기 위해 오스카 가정에 들어오게 된다. 마리아는 오스카의 첫사랑이 된다. 비등산 놀이는 오스카로 하여금 세 번째 북채(남성 성기의 은유)를 사용하게 했는데 그것을 사 용할 만큼 오스카가 자라게 된 것이다. 마리아는 오스카와 바닷가에 수영도 같이 다닐 만큼 친밀해진다. 하지만 오스카 는 마리아가 마체라트와 성관계하는 것을 보게 된다. 마리아 가 임신을 하게 되고 마체라트는 마리아와 혼인한다. 마리아 는 아들 쿠르트를 낳게 된다. 오스카는 아기 쿠르트를 자신 의 아들로 생각한다. 오스카는 자신의 어머니인 아그네스가
마리아를 만난다는 상상을 한다. 오스카의 상상 속에서 어머 니인 아그네스는 마리아의 뺨에다 다정한 키스를 하고 눈짓 을 하며 말한다. '참 이상한 일이야. 누가 알았겠어. 우리 두 사람 모두 마체라트와 결혼해서 브론스키를 길렀잖아'(Grass 1999)." 이런 방식으로 오스카는 아그네스와 마리아를 한 존 재로 융합하였고, 마리아와 아버지 사이의 아들을 자신의 아 들로 인식하는 것으로 간접적인 근친상간적 소망(incestuous wish)을 성취한다. 이런 부분도 이 소설이 뚜렷한 오이디푸 스 콤플렉스의 표현으로 볼 수 있는 면이다.

한편 저자는 친어머니인 아그네스의 애인이며, 삼각관계 의 축을 담당하는 얀 브론스키에게는 귄터 그라스 자신의 일 부를 투사했다고 생각한다. 귄터 그라스의 어머니가 사랑했 으나, 젊은 나이에 전사한 외삼촌들의 예술가 기질을 자기 삶의 이정표로 삼았었다고 그는 자서전에서 이야기했다. 귄 터 그라스 자신이 동일시했다고 고백했으며, 어머니가 잊지 못하고 유품까지 간직하며 사랑했던 오빠들이 얀 브론스키 의 모델이었을 것 같다. 소설 속에서 어머니인 아그네스가 사랑했던 얀 브론스키는 아그네스의 사촌오빠였다.

소설 속에서 반복되는 삼각관계, 분노와 질시와 죄책감

(1) 어머니 아그네스와 사촌인 얀브론스키와 마체라트의 삼각관계

‘슈토크 탑에서 울려 퍼지는 노래'에서 다음과 같이 노골 적이고도 재미있게 묘사되었다. "어머니는 매주 목요일에 시내로 물건을 사러 갔다. 대개의 경우, 나를 데리고 갔으며 시장 근처 병기창 거리에 있는 마르쿠스의 가게에서 새 북 을 살 필요가 있을 때는 언제나 데리고 갔다. 가게를 방문할 때마다 정각 네 시 반이 되면, 어머니는 중요하고 급한 일이 아직 남아 있어 나를 마르쿠스의 가게에 맡겨 두고 싶다고 그에게 부탁했다. 그러면 가게 주인인 마르쿠스는 이상한 미 소를 지었다. 어머니는 얼굴을 붉히며, 마르쿠스가 사정을 알고 있음을 어렴풋이 느꼈다. 나 역시 어머니가 중요하다고 말하면서 아주 바쁜 듯이 사라지는 이유가 무엇인지 알고 있었다. 한동안 티실러가쎄의 어느 값싼 하숙집으로 어머니 를 따라가 본 적이 있기 때문이다. 어머니는 그곳 층계에서 사라졌다가 꼭 45 분 뒤에 돌아왔다. 어머니는 거의 얼굴빛도 변하지 않은 채 돌아와서, 안주인에게 인사 한 마디를 하고 기다리던 나의 손을 잡곤 했다. 그때 손의 체온이 그녀의 비 밀을 누설하는 것을 그녀는 까맣게 모르고 있었다. 손을 잡 은 후 우리들은 볼베버가쎄의 카페 바이츠케로 갔다. 어머니 가 자신을 위해서 모카를, 나를 위해서 레몬 아이스크림을 주문하고 있으면, 곧 우연인 듯한 표정으로 얀 브론스키가 
나타났다. 그는 우리들의 테이블에 앉자 똑같이 모카커피를 시켜 흥분을 식혀 주는 차가운 대리석 테이블 위에 놓게 했 다. 티실러가쎄는 물론이거니와 카페 바이츠케에도 나를 더 이상 데리고 오지 말라고 한 것은 아마도 얀이었을 것이다. 그는 때때로 매우 부끄러워했는데 어머니보다 훨씬 더 부끄 러움을 탔다. 밀회가 끝난 뒤에 내가 함께 있어도 어머니는 태연히 밀회의 정당성을 언제나 확신하고 있는 듯하였다. 오 스카는 분노해서 유리를 부순다. 어느 목요일 오후, 오스카 는 마르쿠스의 가게를 나와 스토크 탑 위로 올라간다. 오스 카는 상공 약 30 미터 되는 높은 탑 위에서 소리를 지른다. 전 에는 오스카에게서 북을 빼았으려할 때만 소리를 질렀었다. 오스카에게서 북을 빼앗으려고 하는 사람은 아무도 없었다. 그럼에도 불구하고 오스카는 소리를 지른다. 겨우 15 분 만에 오스카는 로비의 모든 창과 문의 유리를 파괴하는 데 성공한 다(Grass 1999).” 오이디푸스 콤플렉스의 주요 축인 삼각관 계와 그에 따른 좌절과, 분노, 질시를 읽을 수 있다.

남편인 마체라트의 분노와 질시, 아그네스의 죄책감은 '성 금요일에 식사'에서 간접적으로 그러나 확실하게 묘사된다. 이 부분도 원문이 유머러스하며 재미있다. "성금요일에 어 머니 아그네스와 마체라트, 얀 브론스키, 오스카는 전차를 타고 브뢰젠 거리를 지나 제방 첨단에 있는 항로 표지까지 뛰어간다. 제방 위는 너무 추웠고 그래서 그곳을 떠나려했 다. 그때 부두 노동자 모자를 쓴 사나이가 제방 위에서 밧줄 을 잡아당기기 시작했다. 아그내스는 여전히 가자고 했다. 하지만 마체라트는 그 자리에서 움직이지 않았다. 사나이는 물방울이 뚝뚝 떨어지는 무언가 무거운 덩어리를 그들 사이 에 던졌다. 아그네스는 제때에 얼굴을 돌리지 못해 그 광경 을 보고 말았다. 그것은 말 대가리였다. 부두노동자는 장화 로 말 아가리를 벌리게 하고, 막대기 한 개를 턱 사이에 밀어 넣었다. 그리고 그는 말의 아가리 속에 두 손을 밀어 넣고는 팔뚝만큼 굵고 긴 뱀장어 두 마리를 재빨리 잡아내자 아그 네스도 큰 입을 딱 벌렸다. 그리고 그녀는 아침에 먹은 것을 제방의 돌 위에 전부 토하기 시작했다. 마체라트가 집에 돌 아와 그 뱀장어를 수프로 만들어, 거실의 테이블에다 늘어놓 았는데, 아무도 자리에 앉으려고 하지 않자 굳이 자신의 요 리를 선전하며 먹기를 권했다. 아그네스는 카슈바이 말로 외 쳤다. 그리고 소리칠 때면 언제나, 아그네스는 오스카의 추 락 사고의 원인으로, 지하실 층계 문을 열어놓았던 마체라트 의 책임을 추궁하는 말을 했다. 성 금요일이 지나고, 어머니 인 아그네스에게도 수난기가 시작되었다. 그것은 5월의 상 쾌한 날씨도 어쩔 도리가 없는 수난이었다. 하지만 마체라트 가 아그네스에게 강요해서 다시 생선을 먹게 한 것은 아니었 다. 아그네스는 자발적으로 그리고 수수께끼 같은 의지에 사
로잡혀, 부활제가 지난 지 겨우 두 주일 만에 생선을 먹기 시 작했다. 그녀는 자신의 몸매를 생각지 않고 마치 누구에게 강 요당하고 있는 것 같다고 말할 정도로 많이 먹은 것이다. 그 들 모두의 식욕이 없어질 정도였다. 그리고 하루에도 몇 번씩 그녀는 토했다. 마체라트는 걱정이 되어 '임신한 것 아니야? 아니면 어디 잘못된 것 아니오?라고 물었다. 신선한 감자가 딸린 녹색 뱀장어를 생크림에 띄워서 점심상에 내 놓은 어느 일요일, 갑자기 그녀는 일어서서 오스카를 들어 올려 꼭 껴안 고, 오스카에게 공복의 심연을 보여주었다. 그것은 그 무엇에 의해서도 채울 수 없을 만큼 큰 것이었다. 그날 밤, 아그네스 는 시립 병원에 운반되어야 했다. 마쩨라트는 구급차가 오기 전에 울면서 아그네스에게 말한다. '도대체 어째서 당신은 아 이를 원하지 않는 거야. 누구의 아이든 상관없잖아? 아직도 그 흥한 말 대가리를 생각하고 있는 건가? 그런 곳에 안 갔더 라면 좋았을 걸. 자, 잊어버려요, 아그네스. 나는 일부러 그러 려고 한 게 아니야.' 구급차가 와서 아그네스를 운반했다. 홀 라츠 박사는 황달과 생선 중독이라고 말했다. 그녀는 임신 3 개월이었고 별실이 주어졌다. 그녀는 토하면서도 이따금 오 스카에게 미소를 지어 보였다. 그래서 마침내 4일째 그녀는 정말 기진맥진한 상태로 죽어갔다. 그녀가 씻겨지고 수의를 입힌 채 뉘어지자, 간호부장이 어머니의 눈꺼풀을 감겨 주어 야했다. 마체라트도 얀 브론스키도 울고 있어서 눈이 멀었기 때문이었다. 모두 울고 있는데 오스카만은 울 수가 없었다. 실제로 어머니의 죽음은 거의 오스카를 놀라게 하지 않았다. 어머니를 따라 목요일에는 고도를, 토요일에는 성심교회를 다니던 오스카에게는 어머니가 수년 전부터 삼각관계를 청 산하는 하나의 가능성을 진지하게 찾고 있는 것같이 생각되 었기 때문이다. 지루한 장례식이 진행되는 동안 오스카는 금 방이라도 어머니가 머리를 쳐들고 다시 한 번 토하지 않으면 안 될 것이라고 생각한다. 그러나 그녀는 구토증을 일으키지 않았다. 오스카는 어머니가 뱀장어를 감추고는 함께 땅 속에 서 마지막 안식을 얻기로 작정한 것이라 생각한다(Grass 1999)." 아그네스는 성당에서 고해를 하지만 자신의 맹목적 인 정열과 삼각관계를 포기하지 않은 채 생선 중독자로 죽 는 길을 택한다.

(2) 마체라트와 계모인 마리아와 오스카의 삼각관계

“마체라트가 죽고, 전쟁이 끝난 후, 오스카는 석공으로 일 하며 마리아와 쿠르트를 도와준다. 이 무렵 오스카는 자신의 첫사랑이며 계모인 마리아에게 정식으로 구혼한다. 오스카 는 마리아와 자신을 위하여 영화 입장권을 사고, 마리아의 용 모를 칭찬한 후 마침내 대담하게 구혼을 한다. 마리아는 거절 의 이유를 산더미 같이 늘어놓으며 그의 소맷자락을 만지작 거리며 다정한 오스카라고 부른다. 거듭해서 간절하게 부탁 
했건만 결혼만은 승낙하기를 거부한다. 그리고 마리아에게 는 새로운 구혼자, 이혼남인 슈텐첼이 나타난다. 그러나 마리 아는 누구와도 결혼하지 않는다(Grass 1999).” 이 역시 명백 한 삼각관계다.

(3) 양파 주점에서 우는 손님들의 사연

오직 울기 위해 비싼 값을 치르고 양파를 써는 소님들의 사연에도 삼각관계에서 오는 좌절과 고통이 주를 이룬다.

(4) 베브라와 로비스타 그리고 오스카의 삼각관계

"43년 오스카는 전선극장의 일원이 되어 전쟁터로 떠나게 된다. 공군의 병영으로 변해버린 페스탈로찌 학교 앞에서 스 승인 베브라를 만났던 것이다. 베브라가 이끄는 전선극장의 프로그램은 일류였다. 그들은 공연을 위해 파리로 함께 떠난 다. 그런데 베브라의 팔에 로비스타가 매달려 있었다. 베브 라는 본래는 질투가 심했는데 세월이 지나자 로비스타는 묶 어둘 수 없는 여자라는 사실을 이해했다. 게다가 베브라는 전선 극장의 지도자이기 때문에 결혼의 의무를 따를 여유가 없었다. 전쟁 말기 순회공연 중, 스승인 베브라의 연인인 로 비스타와도 일시적인 사랑을 나눈다(Grass 1999)." 이 역시 아버지 같은 스승의 연인과의 삼각관계여서 오이디푸스 콤 플렉스의 표현이라 생각된다.

(5) 무명지 사건

소설의 대미를 장식하는 사건도 삼각관계에서 비롯된 질 투에 의한 살인사건이다. "독일 패전 후에 오스카는 순회 공 연으로 많은 돈을 벌게 된다. 그러나 비싼 집은 구하지 않는 데 왜냐하면 마리아와 아이 그리고 마리아의 누이에게 얼마 간의 생활비를 대는 것을 자신의 의무로 생각했기 때문이다, 새로 구한 집에는 다른 세입자가 있었다. 그녀는 도로테아라 는 이름의 간호사였다. 그리고 그녀는 근처에 마리아병원에 근무하고 있으며, 베아테라는 간호사와 친하다는 것을 알게 된다. 우편엽서들을 볼 수 있어서 알게 되었다. 편지들 중에 는 마리아 병원의 에리히 베르너 박사가 도르테아 간호사에 게 보낸 것도 있었다. 그 의사는 도르테아 간호사를 연모하 고 있었다. 당시에 오스카는 질투심에 눈이 멀어 당장에라도 의학을 공부하여 가능한 빨리 의사가 되고 싶었고, 그것도 마리아 병원의 의사가 되고 싶다고 상상한다. 어느 날 도르 테아 간호사의 방 문이 잠겨 있지 않은 것을 발견하고 그 방 에 몰래 숨어들어가기까지 한다. 그는 간호사의 옷장 안에 검은 에나멜 벨트를 본 후, 성금요일에 어머니와 방파제에서 봤던 뱀장어와 어머니를 연상하게 된다. 그리고 그 안에서 자위를 하게 된다. 마리아병원의 간호사인 도르테아와 베아 체, 베르너 박사와 오스카가 얽혀있다. 그런데 도르테아가 살해되고 반지를 낀 무명지가 잘리는 사건이 발생한다. 그 무명지를 우연히 습득해 유리병 속에 보관하고 있던 오스카
는 살인범으로 몰려 유죄 판결을 받는다. 그러나 정신과 환 자로 분류되어 정신병원에 수감된다. 누명 쓴 살해범으로서 정신병원에서 하는 오스카의 회상이 양철북이라는 소설의 내용이다. 2년 후에, 도르테아의 친구이며 간호사인 베아체 가 베르너 박사를 향한 사랑에 미쳐서 질투심 때문에 간호사 도르테아를 호밀밭으로 꾀어내어 살해한 것으로 밝혀진다 (Grass 1999)." 그 내용에도 오이디푸스 콤플렉스의 주제인 삼각관계와 사랑과 질투와 분노가 녹아있음을 읽을 수 있다.

\section{전지전능감에 대한 환상과 공격성}

"양철북을 치는 능력과 소리 질러 유리를 깨는 능력으로 어머니에게 고통을 주고, 학교를 다니지 못하게 된다. 이 괴 력으로 자신의 양철북을 어머니마저도 손 댈 수 없게 하고 선생님이나 의사 등 어른들을 통제한다. 사랑의 경쟁자인 얀 을 좀도둑으로 만들기도 한다. 반제머 씨의 보석상 앞에 얀 브론스키가 서있었다. 오스카(작가)의 얀에 대한 묘사다. '우 아하지만 측은해보이며, 직업에서는 굴종적이고, 애정에서 는 야심적이며, 어리석은 동시에 탐미적인 얀 브론스키. 나 의 어머니의 육체에 의지해 살고, 마체라트의 이름으로 나를 낳은 얀이 바르샤바의 양복점에서 맞춘듯한 우아한 외투를 입고 서있었다.' 오스카는 지옥의 문처럼 보석상의 유리를 뻥하니 뚫었다. 얀은 꼼짝도 하지 않다가 이윽고 외투 주머 니에서 고급 장갑을 낀 손이 나와 지옥 속으로 미끄러져 들 어갔다. 이 후에 얀 브론스키는 아그네스에게 거기서 집어낸 목걸이를 선사한다. 나치의 선전장을 왈츠를 추는 무대로 망 가뜨리기고 하며, 반 나치 청소년조직인 먼지떨이단에서는 예수로 추앙 받으며 대장이 된다. 전국적인 전선 순회공연자 의 일원이 되기도 하고, 북소리로 사람들을 조정하는 모습이 양파주점에서 극적으로 묘사된다. 전후에는, 기획사와 계약 하여 스타가 되며 큰 돈도 벌게 된다. 마리아는 슈텐첼과 헤 어졌고 오스카의 도움으로 일급의 식료품점을 세웠으며 가 게는 번창하여 지점까지 세웠다(Grass 1999)." 오이디푸스기 의 주요 환상인 전지전능감과 공격성을 읽을 수 있는 내용 들이다.

퇴행과 고착

왜 주인공인 오스카는 하필이면 세 살에 지하실 계단에서 떨어지며 자라지 않기로 결심했는지, 또 왜 아그네스는 세 살이 되면 양철북을 주겠다고 약속했는지를 정신분석적으 로 고찰하면, 퇴행과 고착의 개념으로 이해할 수 있다.

귄터 그라스는 17 세에 자신의 강열해지는 오이디푸스 소 망과 좌절을 피해 전쟁터로 도망쳤었다. 자신이 도망쳤던 전 쟁터에서 온 후에, 20 대 후반의 귄터 그라스가 현실에서, 비 
밀스런 수치와 자책과 좌절을 벗어나기 위해 도망칠 그의 과거는 그의 오이디푸스기인 것이 당위일 것이다. 귄터 그라 스는 참전 당시 자신이 너무 어렸었다고 자책했는데, 그의 무의식은 그가 얼마나 어린가하면, 바로 세 살이었다는 것을 알고 있었던 것이다. 재미있는 것은 소설 속의 오스카가 계 단에서 스스로 굴러떨어지던 세 살 때가 1927년이었는데, 이 해는 귄터 그라스가 탄생한 해이기도 하다. 정신분석에서 는 이를 퇴행과 고착이라고 한다(Freud 1963b).

소설 속에 오스카가 계단에서 떨어지는 자해의 행위는 Choi(2017)가 그의 논문에서 이야기한 '자기애적 피학적 성 향'의 측면에서 고찰해 볼 수 있다. 즉 Cooper(2009)에 의하 면 아이에게 자기애적 전능감은 중요한 요소인데, 지속적으 로 자기애적 상처를 입다보면 이러한 전능감에 상처를 입고 그 상황을 견딜 수 없게 된다는 것이다. 결국, 아이는 자신이 원해서 고통을 받는 것이라는 피학적인 성향을 발달시킴으 로써 자신에 대한 전능감을 유지하게 되고 그 상황을 방어하 게 된다는 것이다. 자해함으로서 세 살에서 성장을 멈춘 오 스카도 양철북을 두드리며 전능감과 공격성을 지니게 된다. 이 내용은 이 소설을 쓴 귄터 그라스의 가장 중요한 환상 중 하나였을 것이다.

소설 속의 '양파주점'에서는 마치 정신치료의 자유연상처 럼 자신의 이야기를 털어놓으며, 퇴행하는 모습들이 극적으 로 묘사되어 있다. "오스카가 세들어 살던 집에는 클레프도 세 들어 살고 있었다. 클레프는 플루트와 재즈 클라리넷 연주 자였다. 둘이서 같이 몇 시간이고 연주할 기회를 가지게 됐 다. 연주한 바로 그날 클레프가 재즈 악단을 함께 만들지 않 겠느냐고 오스카에게 제안을 한다. 그리고 오스카는 재즈밴 드에서 드럼 치는 사나이가 되기로 결심한다. 그 후에 클래프 가 마침내 찾아낸 솔레라는 이름의 기타주자가 합류한다. 그 들은 매일 아침 라인 강 오른편 물가에 앉아 음악을 연주했 다. 그들은 〈더 라인 리버 스리〉라고 이 신생 악단에 이름을 붙인다. 그들이 라인 강변을 사랑한 것 같이 주점 주인인 쉬 무도 라인 강변 오른쪽 기슭을 사랑했다. 그들이 연주하는 동 안 쉬무가 참새를 사냥하는 총성이 울렸다. 그는 한 나절 동 안 열두 마리 이상은 결코 잡지 않았다. 그는 밴드의 멜로디 와 리듬에 맞추어 탕 하고 사격을 했다. 쉬무는 밴드가 그의 주점에서 연주해 주기를 청했다. 정말로 양파 주점은 진짜 켈러(지하 술집)로서 다소 습기마저 느껴졌다. 이 술집이 다 른 집과 다른 점은 값이 지나치게 비싸다는 것뿐이었다. 따 라서 손님들은 대개 사업가, 의사, 변호사, 예술가, 배우, 고 관들로서 요컨대 인텔리를 자처하는 사람들이었다. 좌석 설 비는 조잡했다. 보통 나무 상자에다 양파 부대를 둘러친 것 이다. 메뉴도 없고 웨이터도 없었다. 깨끗하게 닦아놓은 판
자 조각과 식칼을 주인인 쉬무는 손님들에게 나누어 주면서 돌아다녔다. 동시에 그는 양파를 분배했다. 식칼을 가지고 신사 숙녀들은 양파 껍질을 벗겼다. 그리고 양파를 썰다보면 쉬무의 손님들은 아무것도 보지 못했다. 눈물이 앞을 가린 것이다. 양파즙은 이 세상과 세상의 슬픔이 달성하지 못한 것을 달성했다. 즉 둥근 눈물을 흘리게 한 것이다. 일동은 울 었다. 조심스럽게 울다, 끝없이 울었으며 염치없이 울었다. 양파 주점의 손님들은 양파를 향유한 후, 옆에 사람들에게 마음을 털어놓기 시작한다. 어떤 질문이든 대답을 하며 마치 외투를 뒤집는 것처럼 자신을 뒤집어 보였다. 밴드는 손님들 이 마음껏 울고 수다를 떨었다고 생각하면 곧 일상적인 이 야기에 어울리는 음악을 연주해 손님들이 이곳을 쉽게 떠나 도록 했다. 그래야 새로운 손님을 받을 수 있었다. 오스카는 양파 같은 것이 없어도 불쌍한 어머니와 우둔한 얀 브론스 키, 마체라트가 묘지에 누워있다는 것을 생각하면 양파가 없 어도 눈물을 흘릴 수 있었다. 어느 날 식칼이 있는 곳에서 격 앙된 싸움이 벌어질 위기가 생겼었다. 음악으로 소란을 잠재 워야했다. 오스카가 치는 북의 음조는 옛날 길을 오락가락하 며 세 살짜리 어린애의 눈에 비친 세계를 재현시켰다. 오스카 는 북소리로 군중을 속박시키고 나서 그들을 포사도브스키 거리에 있는 유치원으로 데리고 갔다. 벌써 그들은 아래 턱을 축 늘어뜨리고, 서로 손을 이어 잡고, 발 끝을 안쪽으로 움직 이며, 유괴자인 오스카가 오기를 기다리게 되었다. 오스카는 신사 숙녀들에게 우선 시험적으로 〈구워라, 구워라, 과자〉를 가르치고, 그것이 성공하자 장내에는 순진한 명랑성이 넘쳐 퍼졌다. 그러고서 오스카는 이 원아들을 행진 대열로 서게 하 고는 이 줄을 이끌고 양파 주점 안을 걸었다. 마치 옛날의 예 시켄탈 거리를 지나 언덕을 오르는 기분이았다. 그러고서 오 스카는 주인인 쉬무도 포함한 전원에게, 함께 지낸 유치원의 오후를 기념하기 위해서 오줌 싸는 것을 허용했다. 오스카는 북으로 자, 해도 좋아요 하고 말했다. 그러자 그들은 유아의 욕구를 충족시키면서 오줌을 쌌다. 신사 숙녀들이 모두 오줌 을 쌌다(Grass 1999)." 소설 속에서, 퇴행을 이처럼 극적이고 도 재미있게 묘사했다.

마체라트의 죽음 후에 성장

마체라트의 죽음 후에 오스카는 독백한다. "자라야 하나? 말아야하나? 나는 이제 스물한 살이다. 나는 고아다. 결국은 자라야 한다. 나의 불쌍한 어머니도 돌아가시고, 나의 추정 상의 아버지인 얀 부론스키도 땅 아래 눕혔다. 그리고 나의 추정상의 아버지인 마체라트를 단지 아버지들에게 신물이 난다는 이유만으로 당 배지를 이용하여 죽였으니 말이다. 나 에는 이제 마리아와 쿠르트, 이 두 사람을 지킬 책임이 주어 
졌다. 오스카는 '자라야한다’라고 말하면서 마체라트의 관 위에다 북과 북채를 던졌다. 그러자 그도 성장하기 시작한 다. 심하게 코피가 났다. 오스카는 45년 6월 마리아와 쿠르 트와 함께 단치히를 떠나 뒤셀도르프로 갔다. 키는 1미터 23 센티미터까지 자랐다. 그리고 이때는 독일의 패전 후였다. 오스카는 서툴지만 쓸 수 있고 유창하게 읽을 수 있고 혹이 생겨나 꼽추이기는 하지만 꽤나 건강한 한 젊은이가 되었고 이제부터는 성인으로서 새로운 삶을 시작하겠노라고 다짐 한다. 이후 가장으로서의 역할도 하며, 도르테아 간호사를 연모하며 전신국 교환수들과 데이트도 한다(Grass 1999)."

오이디푸스기 이후의 성장을 이야기하는 느낌이 든다. 아 버지로 여긴 이의 죽음 이후에야 비로소 퇴행으로 고착되었 던 성장을 시작하는 것은 오이디푸스 콤플렉스의 무의식적 해소와 이후의 성장을 의미한다. 마치 프로이트가 아버지의 죽음 이후에 비로소 로마를 방문하게 된 것과도 일맥상통한 면이 있다.

소설 속의 오스카는 자라기는 했지만, 여전히 120 센티미 터 정도의 키이며 등에는 커다란 혹이 생긴다. 이 부분은 결 론에서 고찰하고자 한다.

소설 속 인물들이 범죄와 죄의식을 처리하는 양상들

앞서 언급했듯이 오이디푸스 컴플렉스의 해소에 죄책감 의 개념은 상당히 중요하다. 아이는 자신이 반대편 성의 부 모에게 보복당할 것이라는 거세 불안이나 사랑을 잃을 것이 라는 두려움을 느낀다. 무의식의 방어기제인 억압의 과정을 거치며 오이디푸스 콤플렉스는 점차 무의식적 소망과 무의식 적 두려움이 된다. 그리고 이것이 후에 새로운 정신구조를 만 드는데, Freud는 이를 초자아라 했다. 즉 이는 오이디푸스 갈 망에 대한 부모로부터의 금기를 아이가 내면화(internalize)하 며 형성한다고 했다. 이제 새로 형성된 초자아 또는 양심에 의해 아이는 죄책감을 느낀다(Freud 1924). 귄터 그라스는 그의 소설 양철북에서 죄책감의 문제를 다양한 인물을 등장 시키며 묘사했다.

\section{(1) 외조부 콜라야체크}

"방화범이었던 그가 방화의 유혹을 느낄 때마다 부억 식탁 위에 놓여진 성냥마저도 밖으로 집어 던지는 바람에 가족들 은 가끔 램프 불을 붙이지 못하고 어둠 속에 앉아 있어야 했 다. 14년이 지난 1913년, 뗏목공으로 일하며, 의용소방단으로 불길에서 인명도 구출한 브랑카가, 사실은 방화범인 콜야이 체크라는 것을 알아본 사람이 있었다. 그는 캐묻는 대신에 시 가를 입에 물고 그의 옆에 서서 불을 붙여 달라고 했다. 이 불 이라고 하는 한 마디, 그리고 성냥이라고 하는 한 마디를 들
은 콜야이체크는 얼굴이 붉어졌다. 수배된 그는 땟목 아래 물 속으로 뛰어들어 영원한 이별을 고했다. 그의 시체는 발견되 지 않았으며, 그냥 미국에 가서 거부가 되었다는 풍문만 있다 (Grass 1917)." 그는 죄를 지었지만 자기 죄에 대해, 도망자답 게 떳떳하다. 단지 얼굴을 붉힐 뿐이다. 그리고 영원히 도망 자의 길을 선택한다. 죄책감의 측면에서 보면, 자아가 강한 인물로 묘사된다.

(2) 아그네스

자신의 불륜을 괴로워하며 신부에게 고해하지만, 맹목적 인 정열을 포기하지 않고 생선 중독자로 죽는 길을 택한다. 즉, 금지된 욕망에 몰두하며 자신의 생명을 스스로 거세시키 는 인물이다. 죄책감의 측면에서 보면 욕동도 자아도 강하지 만 숨겨진 강한 초자아에 결국은 굴복하는 인물로 묘사된다.

(3) 헤어베르트 트루친스키

"오스카의 첫 친구로 등장하는 트루친스키는 선량한 사람 이다. 어머니가 돌아가시고, 열네 살이 된 오스카는 항구 거리 에서 일하는 헤르베르트를 친구로 사귀었다. 시내 선술집에 서 웨이터로 일하는 헤르베르트는 종종 싸움에 휘말리느라 구급차에 실려 집에 오곤 했다. 그의 등에 난 상처 하나하나 를 생각할 때마다 오스카는 항상 앉아서 북을 쳤다. 헤르베르 트가 레트 인 선장을 죽이게 되는 사건이 생긴다. 그의 정당 방위였기 때문에 무죄판결을 받았지만 다시는 일하러 나가지 않았다. 얼마 후 헤르베르트는 새로운 직장과 제복을 얻었다. 해양박물관의 수위가 된 것이다. 해양박물관에는 니오베라 는 목각상이 보관되어 있었는데, 여러 명의 남자들이 그녀의 발밑에서 죽었다. 그래서 박물관 수위를 지망하는 사람이 없 었던 것이다. 결국 박물관 관리인으로 취직한 헤르베르트도 예외 없이 니오베의 저주에 사로잡혀 목각과 교미하려고 시 도하다가 목숨을 잃는다(Grass 1999)." 헤어베르트 트루친스 키는 자신의 죄가 아닌 것을 자책하며 괴로워하다 스스로 자 멸의 길로 빠져드는 인물이다. 죄책감의 측면에서 고찰하면 초자아가 지나치게 강해서 희생당하는 인물로 묘사된다.

(4) 양파주점의 주인 쉬무

“쉬무는 라인 강변에서 참새를, 오로지 12마리만을 총을 쏴 잡곤 했다. 그러나 사신이 쉬무를 데려가는 사건이 발생 한다. 사건의 전모는 이렇다. 매일 12 마리의 참새를 잡던 쉬 무 앞에 너무나 눈에 띄는 표본이라 할 만한 참새 한 마리가 내려앉았다. 쉬무는 참을 수가 없어 13번째 참새를 쏘았던 것이다. 정말이지 쏘지 말았어야 하는 순간이었다. 돌아오는 길에 쉬무의 메르세데스는 추락하여 드러누웠고 쉬무는 그 사고로 사망한다. 같이 탔던 쉬무의 부인과 클레프와 솔레는 경상이었다. 그 들의 말로는 수백 마리의 참새가 구름처럼 솟아올라 쉬무의 차를 덮고 유리에 부딪쳐 차의 추락을 유도 
했으니 오직 참새의 힘만으로 가게 주인이 죽었다는 것이다 (Grass 1999)." 죄책감의 측면에서 보면, 쉬무는 자신의 이드 안에 있는 금지된 욕망이 강해서 금기를 깨다가 외부의 처벌 로 자신의 생명을 거세 당하는 인물로 묘사된다.

(5) 오스카와 귄터 그라스

우리의 오스카는 어떤가? "오스카가 전국 순회공연의 계 약을 위해 찾아 간 곳에서 그는 노쇠한 베브라를 만나게 된 다. 오스카는 그에게 세 살짜리 오스카의 이야기를 고백한 다. 내 불쌍한 어머니를 북을 두들겨 무덤으로 데려가고, 얀 부론스키를 적들에게 넘겨주고, 마체라츠에 대한 살인도 고 백했다. 고백을 들은 베브라는 웃었다. 백발을 휘날리며 웃 었다(Grass 1917)"라는 대목이 인상적이다. 오스카는 이 고 백으로 마체라트의 손으로부터 자신을 해방시켰음을 인정 한다. 또한 소설 속에 오스카는 28살에 살인범의 누명을 쓰 고, 2 년을 갇혀 살다가 30살에 진범이 잡혀 무죄로 판명이 된 다. 진짜 범인이 드러났고 재판이 재개된다. 오스카는 무죄 석방되어 정신병원에서 퇴원한다. 귄터 그라스가 30세 되던 해에 쓴, 소설 속 30 세의 오스카는 무죄인 것이다. 소설은 다 음과 같은 오스카의 독백으로 끝난다. "도주 당시 나의 나이 는 28 세였고 오늘은 30 번째 생일임을 떠올렸다. 유죄 판결을 받고 수감되고, 그 후에 석방되어, 오늘 30 번째 생일을 축하 하고 있으며, 그러면서도 여전히 검은 마녀를 두려워하고 있 는 것이다. 이전에는 내 등 뒤에 타고 앉아서 나의 혹에다가 키스했던 그것이 이제는 내 정면에 다가온다. 검은 마녀는 있느냐? 있다 있다 있다!(Grass 1999)"

죄책감에 사로잡혀 양철북을 쓴 30살의 귄터 그라스는 무 죄이고 싶었던 것 같다. 그러나 소설 속의 오스카가 누명을 벗었음에도 소설의 끝은 검은 마녀가 사라지지 않고 있는 것 으로 끝난다. 귄터 그라스는 그 마녀의 추적을 79세가 되어 서 자서전 속에서 진실을 밝히며 벗어날 수 있었을 것으로 생각한다.

\section{그 외에 소소한 소망 충족들}

외조부인 콜라야체크가 방화범이긴 했지만, 폴란드 국기 를 수호하려고 불을 지른 방화범이었다. 마체라트는 독일 나 치 당원이었지만, 자신의 생부로 믿는 얀 부론스키는 독일에 저항하는 폴란드인으로 죽는다. 오스카 자신도 양철북으로 나치의 집회를 교란시키고, 반 나치 청소년 무리인 먼지떨이 단의 대장으로 활약한다. 오스카가 가지기를 고집한 양철북 은 빨강과 흰색이 칠해진 양철북이었는데 이는 폴란드의 국 기를 상징한다. 여러 가지 소소한 관찰들이 아버지로 상징되 는 나치 독일에 대한 저항이라는 측면에서, 그의 소망 충족을 담당했다고 생각한다.
양철북이 가지는 의미

다중적인 의미가 있다. 시대적으로 보면, 나치시대의 양철 북을 두드리는 소년들의 북소리는 히틀러의 연설만큼 선동 적이었으며 정복자, 승리자가 되라는 울림이었다. 또한 소설 속에서는, 마리아와의 성관계를 암시하는 비등산 놀이를 하 며 세번째 북채를 사용했다는 묘사에서 알 수 있듯이, 북채 는 남성성기를 상징한다. 그렇다면 양철북을 친다는 것은 성 행위의 은유라는 연상을 자연히 하게 된다. 작가 자신의 개 인사적으로 보면, 20대 후반의 귄터 그라스는 재즈단원으로 주점에서 일주일에 세 번 연주를 했는데 실제로 그는 양철로 된 드럼을 쳤다고 한다. 양철북 소리는 그를 과거로, 그가 고 착되어 있던 시기로 데려가는 심리적인 도구였던 것 같다. 그 는 그 시기에 세 살배기 오스카가 나오는 양철북을 썼다. 그 리고 그는 그 때의 경험을 소설 속 '양파 주점'에서 잘 녹여서 묘사하고 있다. 즉 양철북은 현재와 과거를 잇는 매개이며 오 스카의 전지전능함과 공격성, 성적인 소망 충족을 상징하기 도 한다.

귄터 그라스는 어떻게 자신의 오이디푸스 콤플렉스를 의식 화했을까?

귄터 그라스는 그의 자서전에서 프로이트를 언급하며 자 신의 오이디푸스 콤플렉스를 자세하개 언급했다. 사실 오이 디푸스 콤플레스는 상당히 무의식에 있는 것이어서 정신분 석을 받아도 상당한 기간이 지난 후에야 어렴풋이 그 내용의 잔재를 엿볼 수 있는 것(Britton 등 1989)으로 알고있다. 귄터 그라스는 어떻게 자신의 오이디푸스 콤플렉스를 의식화할 수 있었을까 궁금해진다. 귄터 그라스가 양철북을 발표할 무 렵인 전후의 서구는 정신분석의 부흥기였다. 귄터 그라스도 정신치료의 경험을 한 것은 아니었을까하는 생각을 해 본다. 소설 속의 아그네스와 얀 브론스키의 밀회 시간이 정해진 시 간인 매주 목요일 그것도 45 분간이었다는 것이 마치 정신치 료의 약속시간과 유사하다는 연상을 하게 한다. 그리고 양파 켈러에서 벌어지는 일도 정신치료와 유사하다. 비싼 대가를 치르며, 능력 있고 인텔리를 자처하는 사람들이 오로지 울며 자기 이야기를 하기 위해 양파를 자른다. 어린아이처럼 퇴행 까지 한다. 월요일은 싼값을 치를 수 있는 대학원생들만을 위 해 양파 켈러를 여는 것으로 되어있다. 귄터 그라스는 가난한 작가 지망생이었으니까, 월요일에 손님들처럼 저렴한 값에, 수련 중인 분석가의 분석을 받았을 수도 있었을 것 같다. 하 지만 이는 어디까지나 저자의 추측이며 공상일 따름이다.

\section{승 화}

방어기제 중 가장 성숙한 것이며 문학이 인간의 고통을 
통해 성취할 수 있는 최상의 것을 귄터 그라스가 달성했음 을 부정할 사람은 없을 것이다. 그는 자기의 내적 갈등과 고 통을 양철북이라는 불후의 명작으로 바꾸어 놓았다.

\section{결 론}

세계명작이 되는 작품들은 그 문체나 구성의 훌륭함뿐 아 니라 인간 본성에 내재한 보편적이며 무의식적 문제를 다룬 경우가 많다. 오이디푸스 콤플렉스를 다룬 작품이 가장 많을 것이라 생각한다. 오이디푸스 왕 이야기에서 시작해 도스토 예프스키의 죄와 벌, 까라마조프가의 형제들, 로렌스의 작품 인 아들과 연인, 유진 오닐의 밤으로의 긴 여로, 느릅나무 밑 의 욕망 등 수많은 작품이 연상된다. 그 중에서도 귄터 그라스 의 '양철북'은 이 주제를 위장은 했지만, 전치시키지 않고 거의 직설적으로 다루었다. 그의 소설이 다소 그로테스크한 느낌 을 주는 것은 아마도 이에 기인할 것이라 생각한다.

귄터 그라스를 이해하려면 무엇보다 그가 나치시대에 유 년기와 청년기를 보냈다는 사실에 주목해야 할 것이다. 동시 대를 산 독일인들은 크건 작건 히틀러와 같은 감정적 경험을 했을 것이라 생각한다. 영국과 러시아를 제외한 전 유럽을 순식간에 장악한 열광의 시기를 같이 맛보았으나, 결국 위대 한 총통은 지하벙커에서 권총으로 자살한다. 귄터 그라스도 독일의 패망과 함께 극한 경험을 한다.

“패잔병으로 쫓기며 같이 생활하던 친구 같은 동료들이 죽고, 사지가 절단되는 부상을 당하는 것을 목격하는 참혹한 경험을 한다. 천신만고 끝에 살아돌아왔으나 집의 상황은 더 욱 참담했다. 귄터 그라스는 패전 후, 자신이 그다지도 사랑 하는 그의 어머니도 러시아군에게서 딸을 보호하기 위해 대 신 몸을 내놓았다는 이야기를 누이동생을 통해 어렴풋이 듣 게 된다. 러시아 군대가 폭력을 휘두르며 들이닥쳤을 때, 도 대체 무슨 일이 일어났는지 그가 알고 싶어하자 그의 어머니 는 ‘나쁜 일은 모두 잊어야 한다......' 라며 아무 말도 하지 않 았다. 그의 여동생은 수녀가 되기로 결정한다(Grass 2015)." 연합군은 전범을 색출하려 하며, 뉘른베르크 전범 재판은 전 세계에 생중계된다. 종전 후 그가 겪었을 비애와 혼란과 공 포와 죄책감과, 자신의 무지와 아버지 세대에 대한 분노를 짐작할 수 있다. 전쟁의 질고를 몸으로 겪었던, 귄터 그라스 의 어머니는 아들이 작가로 성공하는 것을 보지 못하고 이른 나이에 사망한다. 소설 속의 아그네스와 마리아는 그의 어머 니를 상징한다. 실제로 그의 어머니는 남편과 금실이 좋았다. 그런데도 그가 소설에서 아그네스를 금지된 욕망을 따르다 전쟁 전에 스스로 죽는 인물로 묘사한 것이 이해되는 측면도 있다. 아그네스가 사랑한 얀 브론스키가 작가 자신을 투사한
인물이라는 점에서도 이해가 되며, 강제되는 성을 거부한 인 물이라는 데서도 작가의 마음이 이해된다.

Loewald(1980)는 새로운 세대가 과거의 세대를 이어받아 새로운 주역으로 일어나는 것을 넓은 의미에서 아버지를 죽 이는 것이라고 기술하고, 그것이 진정한 오이디푸스 콤플렉 스의 해소라고 하였다. 소설 속의 오스카도 아버지인 마체라 트의 죽음 후 자라기 시작한다. 이 시기는 전쟁이 끝난 후 귄 터 그라스가 양철북을 집필한 시기이다. 그는 이 책을 쓰며, 자신의 정신세계 깊은 곳에 내재되어 있던 갈등을 이해하는 치유의 과정과 아버지 세대에 과오를 벗는 두 가지 작업을 동시에 이룩했다고 본다. 하지만 '양철북', 소설 속의 오스카 는 자라기는 했지만 여전히 120센티 정도의 키에 등에 혹을 달고 있으며, 검은 마녀에게 시달린다. 귄터 그라스는 79세 의 나이에, 그가 쌓아온 모든 것을 잃을 것을 각오하며, 그의 자서전에서 자신의 수치스런 비밀을 밝혔다. 등의 혹과 검은 마녀는 바로 그가 미처 고백하지 못했던 비밀이며, 그의 죄 책감이었다고 생각한다. 그는 40년이 넘게 지난 후, 그가 사 망하기 9년 전에 마침내 등을 펴고 곧게 섰을 것이라 생각하 며 글을 맺는다.

\section{Conflicts of Interest}

The author has no financial conflicts of interest.

\section{REFERENCES}

Auchincloss EL. The psychoanalytic model of the mind. Arlington, VA: American Psychiatric Publishing;2015. p.107-125.

Britton R, Feldman M, O'Shaughnessy E. The Oedipus complex today: clinical implications. London: Karnac Books;1989. p.129-150.

Choi JB. A psychoanalytic approach upon Chong-Jun Yi's autobiographical serial novel's, 'The negative and positive pictures of painful memory'. Psychoanalysis 2017;28:25-26.

Cooper AM. Feature: the narcissistic-masochistic character. Psychiatr Ann 2009;39:904-912.

Freud S. Interpretation of dream. SE 3,4. London: Hogarth Press; 1900.

Freud S. Creative writers and daydreaming. SE 9. London: Hogarth Press; 1908a. p.141-154.

Freud S. On the sexual theories of children. SE 9. London: Hogarth Press; 1908b. p.205-226.

Freud S. The dissolution of the Oedipus complex. SE 19. London: Hogarth Press;1924. p.172-179.

Freud S. Introductory lectures on psycho-analysis (part 3). SE 16, London: Hogarth Press;1963a. p.339-357.

Freud S. Introductory lectures on psycho-analysis (part 3). SE 16, London: Hogarth Press;1963b. p.273-286.

Freud S. Letter 70. Extracts from the Fliess papers. SE 1. London: Hogarth Press;1966. p.261-263.

Grass G. The tin drum. Seoul: Minumsa;1999.

Grass G. Peeling the onion. Seoul: Minumsa;2015.

Kim NL. Allegory and history. Seoul: Minumsa;2003. p.55-56.

Lee MS. Invitation of the psychoanalysis. Seoul: Iu publishing Co;2006. p. 154 .

Loewald HW. The waning of Oedipus complex. In: Loewald HW. Papers on psychoanalysis. New Hayen, CT: Yale University Press;1980. p.384-404. 